The twins, one male the other female, were born almost a year ago at the Anthropoid Experiment Station of Yale University, at Orange Park, Florida. The parents were chimpanzees, the male about eleven years old and the female abour twenty. Although among other primates, such as lemurs, gibbons, baboons and monkeys, twin births, according to Dr. Yerkes, have occasionally been recorded, the higher apes, chimpanzees, orang-outans and gorillas, have not hitherto been known to give birth to more than one young at a time.

\section{Committee on Street Lighting}

The following Departmental Committee has been set up by the Minister of Transport to report on the lighting of streets: Mr. F. C. Cook (deputy chief engineer, Ministry of Transport) (chairman): Mr. J. F. Colquhoun (public lighting engineer, Sheffield); Mr. C. A. Masterman (chief technical officer, Gas Light and Coke Company); Major W. H. Morgan (county engineer, Middlesex); Mr. C. C. Paterson (chairman of the Illumination Research Committee, Department of Scientific and Industrial Research; director of Research Department, General Electric Company); Mr. E. S. Perrin (Ministry of Transport); Major L. Roseveare (borough engineer, Eastbourne); Mr. J. R. Taylor (Ministry of Health); Dr. J. W. T. Walsh (National Physical Laboratory). The secretary of the Committee is Dr. H. F. Gillbe, of the Ministry of Transport, and its terms of reference are: "To examine and report what steps could be taken for securing more efficient and uniform street lighting, with particular reference to the convenience and safety of traffic and with due regard to the requirements of residential and shopping areas, and to make recommendations".

\section{German Association of Men of Science and Physicians}

THe German Association of Men of Science and Physicians will hold its ninety-third meeting in Hanover on September 16-20. The invitation to meet in Hanover is now of more than twenty years' standing. It was accepted at the Vienna meeting of 1913 and planned for the next year, 1914. Since then, the Association has held its centenary in Leipzig in 1922, and has travelled south and west and north and east to Innsbruck, Düsseldorf, Hamburg, Königsberg and west again to Wiesbaden and Mainz. Hanover is easily accessible by land and air. This is the first meeting under the new constitution and an impressive proclamation of German science is desired. Public dinners are to be minimised, but exhibitions and excursions are planned. An associate's ticket costs 20 gold marks, application to be made to Geschäftstelle G.D.N.A., Leipzig, C.1, GustavAdolfstr. 12. A detailed programme is available showing the general addresses and combined sessions, also the 37 separate sections and some twenty allied associations. The Zweckverband provides a brief directory of more than thirty German scientific societies. The exhibition dedicated to "Deutsches Volk--Deutsche Arbeit" is to give a picture of the history of the German race, with emphasis on heredity, genetics and eugenics, and also on chemistry as a domain in which intellectual leadership is fundamental for industry. The local secretaries will be at Hanover, Technische Hochschule, Welfengarten 1. Among the distinguished men- who are already announced as likely to be present are Prof. W. Heisenberg, Dr. Eckener and Dr. Sven Hedin.

\section{Announcements}

THE fifty-third annual meeting of the Society of Chemical Industry will be held at Cardiff on July 16-20, under the presidency of Dr. J. T. Dunn. The presidential address, entitled "Science and Industry -the Fertility of Ideas", will be delivered on July 17. Other addresses include Prof. H. Freundlich on "Plasticity the Servant of Industry", Sir Harry McGowan (to whom the Messel Memorial Medal will be presented) on "The Uneven Front of Research", and Col. C. H. Bressey on "British Roads Development during the past Fifteen Years".

A RECENT Bulletin (No. 70) published by the Ministry of Agriculture and Fisheries (1s.) deals in a thorough way with the keeping and breeding and other activities connected with making the most of "Ducks and Geese".

THE Achema VII Exhibition Guide, a directory of manufacturers of chemical plant and apparatus in Germany, published and issued in connexion with the Achema VII, held at Cologne on May 18-27 (see NATURe, June 2, p. 843) is, we are informed, now available. Copies can be obtained from Dechema, Seelze bei Hannover (1 gold mark, post free).

A volume of "Researches" published from the wards and laboratories of the London Hospital during 1933 has been issued by the Publications Committee, of which Mr. Hugh Cairns is secretary (London: H. K. Lewis and Co., Ltd., 136 Gower Street, W.C.1. 7s. 6d. net). It includes 31 papers dealing with a variety of subjects comprised within the science and art of medicine, and all of them contributing to the advancement of clinical medicine or of medical science.

Applications are invited for the following appointments, on or before the dates mentioned :-A lecturer in pharmaceutics at the Central Technical College, Birmingham--The Chief Education Officer (July 14). An assistant lecturer in zoology at University College, Gower Street, London, W.C.1 (July 18). An assistant keeper (second class) on the higher technical staff of the Industrial Engineering and Manufacturing Department of the Science Museum, South Kensington, London, S.W.7--The Director (July 21). A deputy Government analyst, CeylonThe Director of Recruitment (Colonial Service), 2, Richmond Terrace, Whitehall, S.W.1 (July 31). A senior lecturer in estate management at the Royal Agricultural College, Cirencester-The Principal. Two demonstrators in the Department of Anatomy, University of Cambridge-The SecretaryGeneral of the Faculties, The Registry, Cambridge. 